\title{
Berpikir Kreatif Matematis Siswa Melalui Pendekatan Contextual Teaching And Learning Bernuansa Islami Di SMP Inshafuddin
}

\author{
Fitria \\ Guru SMPN 2 Banda Aceh \\ Email : Fitriyuanda86@gmail.com
}

\begin{abstract}
Abstrak
Berpikir kreatif matematis menjadi hal yang sangat penting dimiliki siswa mengingat kehidupan abad ke-21 menuntut berbagai keterampilan dan kemahiran yang penuh dengan kreativitas. Permasalahan timbul ketika matematika kurang diminati di sekolah yang berlatarbelakang dayah terpadu dimana mereka lebih dominan mempelajari ilmu yang berhubungan dengan keagamaan. Oleh karena itu, pemberian materi dilakukan dengan pendekatan Contextual Teaching and Learning bernuansa islami diduga menjadi solusi untuk permasalahan tersebut. Tujuan dari penelitian ini adalah untuk mengetahui berpikir kreatif matematis siswa melalui pendekatan Contextual Teaching and Learning bernuansa islami di SMP Inshafuddin. Penelitian ini menggunakan metode kualitatif dimana data yang didapat dalam penelitian baik dalam bentuk tes, angket dan wawancara dianalisis secara deskriptif. Hasil penelitian didapat bahwa berpikir kreatif siswa dengan indikator kelancaran, keluwesan dan keterurain dominan bisa dicapai dimana siswa mampu menjelaskannya dengan lancar, memberikan penyelesaian yang beragam serta menguraikan setiap jawaban dengan rinci sedangkan indikator keaslian, sebagian siswa masih memiliki kesulitan dalam menuangkan ide yang unik dan berbeda dari yang lainnya sehingga indikator tersebut susah dicapai oleh siswa. Dari berbagai uraian di atas didapat kesimpulan bahwa berpikir kreatif siswa yang semakin bagus, siswa merasa pembelajaran dengan pendekatan Contextual Teaching and Learning bernuansa islami lebih bermakna karena seirama dengan nilai agama yang mereka pelajari sehingga membuat berpikir kreatif siswa di sekolah berlatarbelakang dayah tepadu semakin baik.
\end{abstract}

\section{Kata kunci: Contexstual Teaching and Learning, Kemampuan berpikir} kreatif

\section{PENDAHULUAN}

Berpikir kreatif matematis menjadi hal yang sangat penting dimiliki siswa mengingat kehidupan abad ke-21 menuntut berbagai ketrampilan dan kemahiran yang penuh dengan kreativitas inovasi (Salehudin, Hassan, \& Hamid, 2015). Selain itu dalam Peraturan Menteri Pendidikan dan Kebudayaan No. 20 tahun 2016 tentang Standar Kompetensi Lulusan menyatakan bahwa lulusan harus mempunyai ketrampilan salah satunya berpikir kreatif (Permendikbud, 2016).

Permasalahan timbul ketika matematika kurang diminati di sekolah yang berlatarbelakang dayah terpadu sehingga berdampak kepada kemampuan berpikir kreatif mereka yang rendah.

Berpikir kreatif memainkan peran penting dalam proses berpikir, banyak pendidik tampaknya kurang memperhatikan kreativitas siswa dalam pembelajaran matematika (Yazgan-Sag \& Emre-Akdogan, 2016). Kenyataan yang terjadi di sekolah selama ini guru hanya mengutamakan logika dan kemampuan hitung-menghitung 
(Amalia, Duskri, \& Ahmad, 2015), sehingga berpikir kreatif dianggap bukanlah sesuatu yang penting dalam proses belajar mengajar di dalam kelas. Penelitian yang dilakukan oleh Rahmazatullaili, Zubainur, \& Munzir, (2017) menyatakan bahwa kemampuan berpikir tingkat tinggi siswa di SMP yang berlatar belakang dayah masih rendah dikarenakan siswa kurang berminat dalam menyelesaikan soal-soal yang membutuhkan banyak strategi, hal tersebut berhubungan dengan banyaknya jadwal pelajaran kedayahan yang mereka pelajari. Oleh karena itu diperlukan pendekatan yang tepat untuk membuat siswa tertarik untuk belajar matematika sehingga mendorong timbulnya kemampuan berpikir kreatif. Pendekatan Contexstual Teaching and Learning diduga menjadi solusi untuk permasalahan tersebut.

Pendekatan Contexstual Teaching and Learning adalah pendekatan pembelajaran yang bertujuan untuk membantu siswa melihat makna pembelajaran yang mereka pelajari kemudian menghubungkan dengan konteks nyata dalam kehidupan sehari-hari mereka (Johnson, 2002). Pembelajaran dengan menggunakan pendekatan Contexstual Teaching and Learning dapat mendorong siswa berperan secara aktif untuk menemukan hubungan materi yang dipelajari dengan kehidupan nyata sehingga pembelajaran menjadi lebih bermakna (Nuridawani, Munzir, \& Saiman, 2015).

Pendekatan Contexstual Teaching and Learning melibatkan tujuh komponen utama pembelajaran efektif, yakni: konstruktivisme (constructivism), bertanya (questioning), menemukan (inquiry), masyarakat belajar (learning community), pemodelan (modeling), refleksi (reflection) dan penelitian sebenarnya (authentic assessment).

Aktivitas berpikir kreatif akan nampak pada komponen kontruktivism dimana siswa membangun pemahaman sendiri secara aktif, kreatif, dan produktif berdasarkan pengetahuan yang dimilikinya. Komponen bertanya juga sarat dengan kegiatan berpikir kreatif dikarenakan berpikir kreatif melibatkan rasa ingin tahu siswa akan sesuatu hal yang akan memunculkan ide-ide baru pada suatu permasalahan tersebut (Johnson, 2011). Selanjutnya aktivitas berpikir kreatif juga nampak pada komponen menemukan dimana penemuan tak akan berhasil tanpa melalui suatu percobaan baik itu mencoba mencari jawaban dengan menggunakan berbagai cara sehingga mereka menemukan suatu jawaban terhadap permasalah maupun suatu konsep.

Pembelajaran dengan pendekatan Contexstual Teaching and Learning tersebut akan disajikan bernuasa islami mengingat sekolah yang ingin diteliti adalah dayah terpadu sehingga siswa lebih termotivasi untuk mempelajarinya. Siswa akan lebih bersemangat apabila materi matematika yang selama ini mereka anggap kaku dihubungkan dengan nilai-nilai agama yang sering mereka pelajari. Anggapan bahwa matematika itu mata pelajaran yang tidak terlalu penting akan hilang seiring dengan pengaitan materi matematika dengan ayat Al-Qur'an dan hadist, sehingga sesuai dengan kehidupan kedayahan yang sedang mereka tekuni.

Pembelajaran islami yang dimaksud pada penelitian ini adalah pembelajaran matematikanya dihubungkan dengan nilai - nilai keislaman yang sering terjadi dalam kehidupan sehari-hari serta dikaitkan dengan ayat-ayat Al-Qur'an (Utami \& Irvan, 2018) dan juga hadist. Al-Qur'an yang merupakan pedoman manusia dan memegang salah satu peranan untuk membentuk dan menunjukan cara berpikir ilmiah dalam matematika tentunya memberikan motivasi pada siswa untuk mempelajarinya (Eka Sasmita \& Mariana, 2018).

Strategi pembelajaran matematika bernuansa islami yang dapat dilakukan dalam pembelajaran matematika adalah selalu menyebut nama Allah seperti membaca 
Basmallah, membaca doa belajar, menggunakan istilah dalam ajaran islam, menggunakan media pembelajaran dan bahan ajar dengan gambar-gambar atau potret yang islami, Menyisipkan ayat atau hadits yang relevan (Gradini, Wahyuni, \& Ansor, 2017).

Pentingnya diterapkan pembelajaran secara islami dikarenakan sesuai dengan kekhususan karakteristik dan budaya masyarakat Aceh yang Islami, dengan demikian proses pembentukan karakter siswa harus didasarkan kepada nilai-nilai islami (Musriadi, Sagala, Ansari, \& Ambarita, 2018). Lahirnya Qanun nomor 5 tahun 2008 menuntut sistem pendidikan Aceh berdasarkan nilai berbudaya Islami, diperkuat dengan lahirnya Qanum nomor 9 tahun 2015 dimana pemerintah Aceh berkewajiban menjamin penyelenggaraan pendidikan yang bermutu, merata, adil dan islami. Oleh karena itu pembelajaran Contexstual Teaching and Learning bernuansa islami menjadi solusi untuk permasalahan yang sudah diuraikan.

Rumusan masalah pada penelitian adalah "Bagaimana kemampuan berpikir kreatif matematis siswa melalui pendekatan Contextual Teaching and Learning bernuansa Islami ?, yang menjadi tujuan dari penelitian ini yaitu Untuk mengetahui kemampuan berpikir kreatif matematis siswa melalui pendekatan Contexstual Teaching and Learning bernuansa Islami.

\section{METODE PENELITIAN \\ Jenis Penelitian}

Berdasarkan tujuan penelitian yang ingin peneliti lakukan yaitu untuk mengetahui berpikir kreatif dan motivasi belajar siswa melalui pendekatan Contextual Teaching and Learning bernuansa islami, maka penelitian ini merupakan penelitian kualitatif. Penelitian ini mendekripsikan data yang didapat dari tes, angket, dan pedoman wawancara yang dianalisis secara deskriptif. Pendeskripsian berpikir kreatif dan motivasi belajar siswa diinterprestasikan secara apa adanya. Moleong (2016) menyatakan bahwa metode kualitatif deskriptif digunakan untuk menggambarkan bagaimana kondisi di lapangan, proses apa saya yang telah berlangsung dengan cara mendiagnosa dan menerangkan hubungan yang terjadi di lapangan dengan kajian teori.

\section{Subjek Penelitian}

Subjek pada penelitian ini adalah siswa kelas VII SMP Inshafuddin Banda Aceh pada semester ganjil tahun ajaran 2020/2021 sebanyak satu kelas yaitu kelas VII-C yang berjumlah 24 siswa. Penentuan subjek penelitian dilakukan secara purposive sampling, yaitu dipilih dengan pertimbangan dan tujuan tertentu (Sugiono, 2017). Subjek dipilih setelah didapat hasil tes berpikir kreatif dan motivasi belajar dimana subjek tersebut diharapkan dapat memberikan informasi sesuai dengan harapan peneliti terhadap berpikir kreatif dan motivasi belajar melalui pendekatan Contextual Teaching and Learning bernuansa islami.

\section{Tehnik Pengumpulan Data}

Teknik pengumpulan data yang digunakan dalam penelitian ini adalah tes, wawancara dan angket.

\section{Tehnik Analisis Data}

Setelah semua data terkumpul, peneliti akan melakukan analisis data menggunakan model Analisis Interaktif dari Miles dan Huberman (1994) yang 
membagi kegiatan analisis menjadi beberapa bagian yaitu: pengumpulan data, reduksi data, penyajian data, dan penarikan kesimpulan atau verifikasi data.

\section{HASIL DAN PEMBAHASAN Hasil Penelitian}

Hasil analisis data berpikir kreatif dan motivasi belajar siswa melalui pembelajaran Contextual Teaching and Learning bernuansa islami akan diuraikan sebagai berikut :

Untuk indikator kelancaran (fluency) didapat bahwa subjek mampu menganalisis soal dengan baik, dimana siswa tersebut membuat penyelesaian dengan memisalkan banyak zikir dengan variabel $\mathrm{z}$ dan waktu yang diperlukan sebagai variabel t, kemudian membuat konsep perbandingan senilai sampai ditemukan hasil akhir yang menjadi pertanyaan pada soal tersebut. Siswa DS mampu menjawab dengan benar dan sangat lancar dalam membuat penyelesaian tanpa adanya kekeliruan. Hal tersebut dapat kita lihat dari jawaban yang dibuat siswa tersebut



Berdasarkan jawaban subjek untuk indikator kelancaran (fluency), subjek siswa DS mampu memahami konsep dari materi perbandingan dengan baik. Ketika peneliti menanyakan apa maksud jawaban dimisalkan dengan variabel, subjek tersebut mampu memberikan penjelasan bahwa memisalkan jawaban dengan variabel akan memudahkan dalam membuat konsep perbandingan sehingga tidak terjadi kekeliruan dalam perhitungan serta langkah penyelesaiannya relevan, subjek mengerjakannya dengan lancar tanpa hambatan meskipun diberikan soal yang lain, sehingga dapat dikatakan memenuhi indikator kelancaran (fluency).

Berdasarkan jawaban subjek untuk indikator keluwesan (flexbility), subjek siswa DS mampu memberikan penyelesaian lebih dari satu cara yang berbeda. Pada cara pertama siswa membuat penyelesaian dengan konsep perbandingan dengan menuliskan seperti penyelesaian pada umumnya, hal yang berbeda ditunjukkan pada cara ke dua dan ke tiga, penyelesaian dibuat dalam bentuk gambar. Walaupun membuat penyelesaian berbeda subjek tersebut mampu menyelesaikan jawabannya dengan benar dan tepat sehingga dapat dikatakan memenuhi indikator keluwesan (flexbility). 


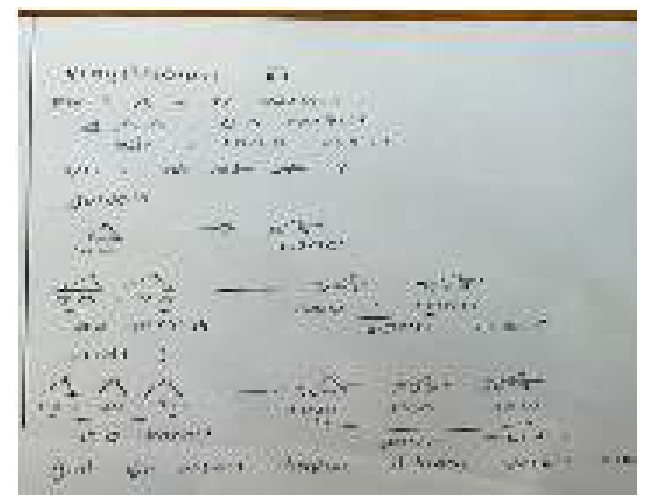

Dari jawaban yang dapat kita lihat di atas siswa DS mampu memberikan penyelesaian yang unik dengan cara menggambar bangun segitiga dan juga bintang sebagai ilustrasi untuk menjawab soal yang diberikan. Siswa tersebut juga tidak mengalami kendala ketika membuat jawaban yang sehingga dapat dikatakan siswa tersebut memenuhi indikator keaslian (originality).

Siswa DS mampu menguraikan jawabannya secara rinci, dimana siswa tersebut membuat penyelesaian dengan menuliskan apa yang diketahui dan ditanyakan dalam soal kemudian menguraikan tahap demi tahap penyelesaian sehingga ditemukan hasil akhir dari permasalahan yang disajikan dalam soal tersebut sehingga dapat memenuhi indikator keterincian (elaboration).

\section{PEMBAHASAN}

Pada bagian pembahasan ini, dijelaskan hasil analisis data yang telah diuraikan pada bagian sebelumnya yaitu bagian hasil penelitian. Pembahasan tersebut akan difokuskan kepada berpikir kreatif matematis siswa dengan pendekatan Contextual Teaching and Learning bernuansa islami dikarenakan berpikir kreatif muncul bukan secara kebetulan melainkan tercipta dengan adanya proses dan persiapan yang merangsang siswa yaitu dengan pendekatan Contextual Teaching and Learning bernuansa islami

Pemberian materi melalui pendekatan Contextual Teaching and Learning bernuansa islami mendorong berpikir kreatif siswa menjadi lebih baik. Hal itu terlihat saat proses belajar mengajar, dominan siswa sudah menunjukkan pemikiran yang kreatif baik saat siswa bertanya maupun saat memberikan jawaban ketika peneliti menanyakan. Siswa memberikan jawaban yang beragam, lain dari pada pernah diberikan oleh temannya serta mampu menguraikannya secara detail.

Adapun kesimpulan dari masing-masing indikator berpikir kreatif akan dipaparkan dalam pembahasan di bawah ini.

\section{A. Kelancaran (fluency)}

Berdasarkan hasil penelitian dapat diketahui bahwa kelancaran siswa ditunjukkan dengan kefasihan siswa dalam menyelesaikan soal yang diberikan peneliti. Selain itu, siswa tersebut juga mampu menjelaskan konsep materi perbandingan dengan tepat serta memberikan ide penyelesaian yang relevan dan benar. Contohnya ketika peneliti menanyakan bagaimana menentukan bahwa perbandingan tersebut senilai, subjek menjawab bahwa dengan menganalisis soal "apabila suatu besaran yang disebutkan di soal meningkat maka besaran lain juga meningkat".

\section{B. Keluwesan (flexibility)}

Pada aspek keluwesan (flexibility) ini, ditemukan bahwa siswa yang mencapai indikator keluwesan juga mencapai indikator kelancaran. Hal ini ditunjukkan dengan hasil tes siswa yang menunjukkan indikator kelancaran, ternyata pada saat wawancara 
siswa juga mampu menunjukkan cara lain dengan pendekatan yang berbeda untuk menyelesaikan soal dengan benar. Siswa yang hanya dapat mencapai indikator kelancaran dan tidak mencapai indikator keluwesan, mayoritas hanya mengacu pada konsep/rumus yang pernah dijelaskan oleh guru atau rumus yang ada pada buku.

Ketercapain indikator keluwesan (flexibility) sangat berkaitan dengan komponen-komponen yang ada pada pembelajaran dengan pendekatan Contextual Teaching and Learning bernuansa islami. Komponen konstruktivisme melatih siswa memikirkan penyelesaian lain dengan berbagai cara dilanjutkan dengan komponen bertanya yang membuat siswa menemukan cara lain dari permasalahan yang diberikan. Adanya komponen pemodelan, siswa mulai belajar bagaimana membuat penyelesaian dengan berbagai cara sehingga ketika diberikan permasalahan siswa mampu menyelesaikan permasalahan tersebut dengan berbagai kemungkinan.

\section{Keaslian (originality)}

Pencapaian indikator keaslian (originality) siswa ditunjukkan dengan kemampuan siswa untuk menunjukkan cara penyelesaian baru dan menghasilkan jawaban yang benar. Siswa yang dapat menunjukkan kebaruan tersebut juga dapat mencapai indikator kelancaran dan keluwesan. Selain itu, berdasarkan observasi, siswa tersebut sangat cepat dalam menemukan solusi dari suatu permasalahan yang disajikan. Hal yang demikian menunjukkan bahwa siswa tersebut mencapai tingkat berpikir kreatif yang tinggi. Indikator keaslian (originality) bisa dicapai siswa tentunya berhubungan dengan komponen yang ada dalam pendekatan Contextual Teaching and Learning bernuansa islami. Komponen konstruktivisme adalah komponen utama yang membangun ide kreatif siswa untuk membuat penyelesaian dengan cara yang baru dan unik dilanjutkan dengan komponen bertanya yang membuat siswa menemukan cara baru dalam mengatasi sebuah permasalahan.

\section{Keteruraian (elaboration)}

Keteruraian (elaboration) merupakan kemampuan siswa yang dapat membuat penyelesaian secara rinci sehingga hasil yang didapat sangat jelas. Pada penelitian ini, hampir semua siswa membuat tahapan atau langkah penyelesaian sebelum sampai ke hasil akhir. Ketercapaian komponen tersebut tentunya erat kaitannya dengan pembelajaran dengan pendekatan Contextual Teaching and Learning bernuansa islami yang mana pada komponen menemukan (inquiri) membantu merangsang siswa pada karakteristik elaboration, dengan jawaban yang telah siswa temukan maka mereka akan lebih mudah untuk memperinci secara jelas jawaban(Artikasari \& Saefudin, 2017).

\section{Kesimpulan}

Sesuai dengan tujuan penelitian dan hasil penelitian, maka diperoleh kesimpulan yang didapat dari hasil analisis dan temuan selama proses penelitian yaitu Berpikir kreatif matematis siswa di SMP Inshafuddin semakin baik dengan pendekatan Contextual Teaching and Learning bernuansa islami. Hasil berpikir kreatif yang didapat oleh siswa Inshafuddin tidak terlepas dari pendekatan Contextual Teaching and Learning bernuansa islami yang mana setiap komponen dalam pendekatan tersebut dapat menstimulus berpikir kreatif siswa sehingga dituangkan dalam penyelesaian soal dimana pada indikator kelancaran, keluwesan dan keteruraian hampir seluruh siswa dominan menguasai indikator tersebut, siswa mampu menjelaskannya dengan lancar, memberikan penyelesaian yang beragam serta menguraikan setiap jawaban dengan rinci sedangkan pada indikator keaslian sebagian siswa sudah mampu memberikan ide 
yang unik namun, ada sebagian siswa masih memiliki kesulitan dalam menuangkan ide yang berbeda dari yang lainnya karena memerlukan waktu lebih lama.

\section{DAFTAR PUSTAKA}

Amalia, Y., Duskri, M., \& Ahmad, A. (2015). Penerapan Model Eliciting Activities untuk Meningkatkan Kemampuan Berpikir Kreatif Matematis dan Self Confidence Siswa SMA. Jurnal Didaktik Matematika, 2(2).

Artikasari, E. A., \& Saefudin, A. A. (2017). Menumbuh Kembangkan Kemampuan Berpikir Kreatif Matematis Dengan Pendekatan Contextual Teaching And Learning. Jurnal Math Educator Nusantara: Wahana Publikasi Karya Tulis Ilmiah Di Bidang Pendidikan Matematika, 3(2), 73-82.

Gradini, E., Wahyuni, S., \& Ansor, A. (2017). Efektivitas Penerapan Pembelajaran Matematika Qurậ $€^{\mathrm{Tm}}$ Ani Dalam Pembelajaran Himpunan. Al Khawarizmi: Jurnal Pendidikan Dan Pembelajaran Matematika, 1(1), 1-20.

Johnson, E. B. (2002). Contextual teaching and learning: What it is and why it's here to stay. Corwin Press.

Johnson, E. B. (2011). Contextual teaching and learning: Menjadikan kegiatan belajar mengajar mengasyikkan dan bermakna (Terjemahan Setiawan Ibnu). Bandung: Kaifa (Buku asli diterbitkan tahun 2002).

Moleong, Lexy. J. 2016. Metodologi Penelitian Kualitatif Edisi Revisi. Bandung: PT. Remaja Rosdakarya.

Musriadi, F. A., Sagala, S., Ansari, K., \& Ambarita, B. (n.d.). Qanun nomor 9 tahun 2015 tentang pendidikan aceh yang diintegrasikan dalam penyelenggaraan pendidikan diniyyah di kota banda aceh.

Miles, Mathew B., dan A. Michael Huberman. 1994. An Expanded Sourcebook: Qualitative Data Analysis. London: Sage Publications.

Nuridawani, N., Munzir, S., \& Saiman, S. (2015). Peningkatan Kemampuan Penalaran Matematis dan Kemandirian Belajar Siswa Madrasah Tsanawiyah (MTs) melalui Pendekatan Contextual Teaching and Learning (CTL). Jurnal Didaktik Matematika, 2(2).

Permendikbud, L. (2016). Peraturan Menteri Pendidikan dan Kebudayaan Republik Indonesia Nomor 20 Tahun 2016 Tentang Standar Kompetensi Lulusan Pendidikan Dasar dan Menengah. Jakarta: Menteri Pendidikan Nasional.

Rahmazatullaili, R., Zubainur, C. M., \& Munzir, S. (2017). Kemampuan berpikir kreatif dan pemecahan masalah siswa melalui penerapan model project based learning. Beta Jurnal Tadris Matematika, 10(2), 166-183.

Salehudin, N. N., Hassan, N. H., \& Hamid, N. A. A. (2015). Matematik Dan Kemahiran Abad Ke-21: Perspektif Pelajar (Mathematics and the 21st Century Skills: Students' Perspective). Jurnal Pendidikan Matematik, 3(1), 24-36.

Sugiyono. (2017). Metode Penelitian Kuantitatif, Kualitatif, dan R\&D. Bandung : Alfabeta, CV

Utami, Y. T., \& Irvan, M. (2018). Analyzing Students' Critical Thinking Ability on Solving Sequences and Series Problems through Problem-Based Learning with Islamic Nuance. International Journal of Scientific Research and Management, 6(01), M-2018.

Yazgan-Sag, G., \& Emre-Akdogan, E. (2016). Creativity from two perspectives: Prospective mathematics teachers and mathematician. Australian Journal of Teacher Education (Online), 41(12), 25. 